\title{
Mu'allim Nâcî'nin Aruza Dair Eseri:
}

\section{ÖMER ZÜLFE*}

\section{ARÛZ NÜMÛNESI}

Muallim Nâci's Work on Prosody: ARUZ NUMUNEsí

Ö Z E T

Aruz Nümûnesi, Muallim Nâcînnin aruza dair eseridir. Müellif, aruz hakkında bir kitap hazırlamak istemiş ve bunun için notlar tutmuş, ancak tamamlamaya firsat bulamamıştır. Müsvedde hâlindeki notları ölümünden sonra Aruz Nümunesi/Takti adıyla basılmıştır. Genellikle beyitlerin taktii üzerinde üzerinde duran Muallim Nâcî, gerekli gördü̆̆̈̈̈ yerlerde açıklamalar yapmıştır. $B u$ makalede, kısa bir değerlendirmenin ardından eserin metin yayinına yer verilmiştir.

A N A H T A R K E L İ M E L E R

Muallim Nâcî, Osmanlı Şiiri, Vezin, Aruz.
A B S T R A C T

Aruz Nümûnesi, is a work of Muallim Naci on the aruz meter. The author wanted to prepare a book on aruz meter and kept notes for it, but he had not been able to complate it. Notes in the form of draft were published after his death under the name of Aruz Nümunesi/Takti. Muallim Naci, mentioning the spelling of aruz usually, have made explanation where necessary. In this article, after a brief assesment we gived the full text of Aruz Nümunesi.

K E Y W O R D S

Muallim Naci, Ottoman Poetry, Meter, Aruz..

Şair ve edip şahsiyetinin yanında, âlim kimliğiyle edebiyat tarihi, lugat, belâgat, tenkit ve tercüme sahalarında değerli kaynak eserlere imza atan Muallim [Ömer] Nâcî [1849-1893]'nin, aruza dair müsvedde hâlindeki notları, ölümünden sonra Hazine-i Fünûn Gazetesi Müdürü ve Asır Kütüphanesi sahibi Kirkor tarafından 'Arûz Nümûnesi/Taktî̀ adıyla kitaplaştırılmıştır (Muallim Nâcî 1895: 24). Muhtemelen müellif, aruz hakkında bir kitap kaleme almak istemiş, bunun için notlar tutmuş, ancak eserini tamamlama fırsatı bulamamıştır.

Aruz Nümûnesi geleneğe bağlı aruz risalelerinde izlenen temel k1sımları içermez. Eserde, adında da vurgulandığı gibi yalnızca Takti bahsi

* Doç. Dr. Marmara Üniversitesi Fen-Edebiyat Fakültesi Türk Dili ve Edebiyatı Bölümü, İstanbul (omerzulfe@gmail.com) 
ele alınarak lafızların vezne tatbiki üzerinde durulmuştur. Nâcî'nin buradaki izahları, Alî Şîr NEVÂYŶ́'nin Mîzânü'l-Evzân'da (Eraslan 1993: 30) Şi'r Taḳțìi başlığı altında verdiği bilgilerle örtüşmektedir.

Eserde, Takti hakkında verilen bilgilerden sonra, Remel'den yirmi bir, Hezec'den on bir, Recez'den yedi vezne dair örnek beyitler zikredilmiş ve yeri geldiğinde açıklamalar eşliğinde lafızların vezne tatbiki gösterilmiştir.

Aruz Nümûnesi, her ne kadar yarım kalmış da olsa ihtiva ettiği malumat bakımından değerlidir. Muallim Nâcî́nin bilgisi ve dikkatiyle örülen notlarda, aruz bilimine dair önemli noktalara temas edilmiş, yeni aruz kitaplarında hemen hemen hiç işaret edilmeyen hususlar hakkında bilgi verilmiştir.

Eserdeki dikkat çekici noktalar şunlardır:

Tamamlanamamış olmasına rağmen, geleneğe bağlı aruz kitaplarında tutulan yola uyulmuş, vezinlerin zihâflara göre uğradığı değişiklikler, ayrıntılarıyla gösterilmiştir. Meselâ, Remel-i Müșemmen-i Makṣūr diye adlandırılan,

Fā'ilātün fã'ilātün fā'ilātün fā'ilāt

Āteşīn rūyuñdan olmış baḳ süveydā garḳ-ı nūr

Ṭūrı gūyā eylemiş berḳ-1 tecellā garḳ-ı nūr

şeklindeki vezin ve örneği,

\section{Fā'ilātün fā'ilātün fā'ilātün fā'ilün}

Āyet-i nūr-1 ruhuñ ol dem ki tertīl eylerem

Rūḥ-1 Dāvūdı menāḳıb-ḩvān tebcīl eylerem

şeklindeki Remel-i Müsemmen-i Mahžūf'tan ayrı bir şekilde ele alınmıştır. Geleneğe bağlı kitaplarda da bu ayrıma dikkat edildiği gibi yine burada olduğu gibi öncelik makșūr biçimlere verilir.

Aynı hususun yalnızca son cüzdeki değişikliklerine değinilmemiş, zihafların bir vezni kendisine mahsus bir hâle soktuğuna dikkat çekilerek bu unsurlar müstakil bir vezin olarak telakkî edilmiştir: 


\section{Fe'ilātün fe'ilātün fe'ilün}

Saña 'ibret vericek yerde fenā

Sen edersin anı ālāt- $\iota$ hevā

Fā'ilātün fe'ilātün fa'lün

Ișțtāḥ üzre tekellüm eyler

Bakup ețāfa tebessüm eyler

Değişiklik gösteren tef'ilelerin birbirinin yerine kullanılabileceği söylendikten sonra mısralar arasındaki tef'ile farklılıklarına işaret edilmiştir:

Gülsitānda / ba'd-ezīn ol / mam ḥarif-i / 'andelīb

Fā'ilātün / fā'ilātün / fā'ilātün / fā'ilāt

Nev-bahārı / ’ömrümüñ geç / di hazānım / söylüyor

Fā'ilātün / fā'ilātün / fā'ilātün / fā'ilün

Yukarıdaki beyitte birinci misraın son cüzü makșūr, ikinci mısraın ise mahzzūf'tur. Serbest mısralarda değişiklik yapılarak bunların ikisi bir birinin yerine kullanılabilir. Ancak şiirin kimliğini belirleyen unsur kafiye ve redif olduğu için bu örnekte olduğu gibi vezin, Remel-i Müssemmen-i Mahızūf diye adlandırılır.

Almaşık ve yeknesak vezinlerin, musammat biçimindeki kullanımlarına ve mısra ortalarındaki iç kafiyeye olan etkilerine temas edilmiştir.

Müstef'ilün müstef'ilïn / müstef'ilün müstef'ilün

Ol āfitāb-1 salțanat / ol şeh-süvār-1 memleket

Müstef'ilün müstef'ilāt / müstef'ilün müstef'ilün

Leşker-şikār-1 kām-kār / Behrām-1 Efrīdūn-'alem

Musammat biçimindeki bu vezinde mısralar, duraklarına göre farklı bir yapıya bürünmektedir. Muallim Nâcînnin dikkat çektiği bu ayrıntı çervesinde yapılacak çalışmalar, böyle vezinlerde ses unsurunun ne şekilde kullanıldığı hakkında fikir verebilir. 
Kimi cüzlerin bugünkünden farklı şekilde takti edildiği görülmektedir. Meselâ, müreddef kafiye ile kurulan şu misrain son tef'ilesi mefā' îlān yerine $f e^{\prime}$ ūlün fā biçiminde adlandırılmıştır:

Uzakdan sey/ r edip de eh / 1-i sa'yi et / me istiṣgāar

Aynı hususun mısra ortalarındaki duraklarda tekrarı söz konusudur.

Müellifin, medli hecelerin takti sırasında kesre ile telaffuz olunması gerektiğini söylemesi, meddin âhenge ne şekilde dahil edildiğini göstermektedir. Muallim Nâcî bu hususu, yār ve āógyār kelimelerine işaret ettiği şu beyitle ifade ediyor:

İsterem bir dem cemāl-i yārdan dūr olmasun

Gizlesün dīdārını āógyārdan her ān niḳāb

Bugün farklı gösterilen vezinlerin, durak yerlerine göre değişik taktiine yer verilmiştir. Yakın zamanda yazılan aruza dair kitaplarda ve metin yayınlarında Mütefā'ilün fe' ūlün mütefā'ilün fe'ūiün biçiminde gösterilen vezni, Muallim Nâcî Remel bahrinden Fe'ilātü fā'ilātün fe'ilātü fā'ilātün şeklinde takti etmiş ve Şeyh Gâlib'in şu beytini örnek vermiştir:

Yine zevrak-ı derūnum kıırllı kenāre düştü

Ṭayanır mı şişsedür bu reh-i seng-sāre düştü

Mu'allim Nâcî'nin geleneğe bağlı bir yöntemle kaleme aldığı bu eseri, her ne kadar yarım kalmış da olsa, günümüzdeki aruz kitaplarından farklı olarak verdiği ayrıntılı bilgiler, takti tercihleri ve önemli noktalara dikkat çeken yönleriyle, ileride yazılacak nitelikli aruz kitapları için kaynak teşkil edecek hüviyettedir. 


\section{ARŪŻ NÜMŪNESİ \\ TAKṬ İ'}

\section{Eser:}

Mu'allim Nācī

Ma'ārif neẓāret-i celīlesinin ruhșatıyla țab' olunmuştur

İstanbul

Kaṣbar Maṭba'ası Bāb-1 'Ālì Caddesinde Numara 25

Ṣāḥib ve Nāşiri

Hazīne-i Fünūn Ġazetesi Müdīiri ve ‘Aṣr Kütüphānesi Ṣaḥibi Kirḳor

1313/1895 


\section{3̉ İfāde-i Mahṣūṣa}

'Ossmānlı naẓm u neșrini bir țarz-1 bihīne ifrāg ile 'ālem-i edebiyātı kendine minnettār eden Mu'allim Nācì Efendi merḥūmuñ-müsvedde olaraḳ-'arūża müte'alliḳ bir parça eșeri elime geçmiş idi. Bu parça, heveskārān-1 edebin istifāde edeceği āsāārdan bulunmaḳla berāber bir 'Ossmanlı 'arūżu vücūda getirmek ārzūsunda bulunacak üdebāya da nümūne olabileceğinden Hazīne-i Fünūn'a derc edildiği gibi ayrıca bir risāle olarak Takțīi' 'unvānı altında dahı neşri münāsib görüldü.

Kitapçı Kirḳor 


\section{${ }_{\perp}^{4}$ Taḳtī}

Eş‘ārıñ evzāna taṭbịịinde ḳullanılan fā'ilātün-mefā'ilün-müstef'ilün gibi mikyāslara efā'îl ve tefā'îl yahud eczā veya erkān denilir.

Bir beyti teşkīl eden iki mıșrā'dan birincisiniñ cüz'-i evveline șadr, cüz'-i ahīine 'arū̇̇, ikincisinin cüz'-i evveline ibtidā', cüz'-i ahīine darb

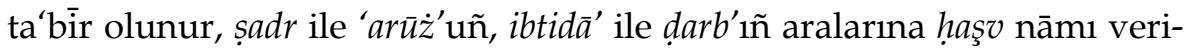
lir.

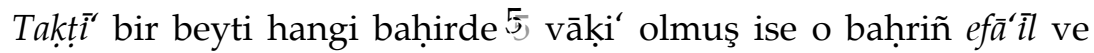
tefă'îl'ine muvāzin olmaḳ üzre parça parça ayırmaḳtan 'ibārettir.

Beytiñ parçalarından her biri efā'îl ve tefā'îl'den birine muvāzin düşer.

Teḳābül eden müteḥarrikleriñ harekeleri bir cinsten olmaḳ lāzım gelmez. Nefs-i harekeye baḳılır; "fetḥa, żamme, kesre"den 'ibāret olan ạ̣vāl-i hạarekeye baḳılmaz.

Esnnā-yı taḳțì de bir fetha bir żammeye veyā bir kesreye, bir żamme bir fethaya veyā bir kesreye muḳābil gelebileceği gibi bir kesre de bir fethaya veyā bir żammeye muḳābil gelebilir. 'ôneselā bir beytte vāḳi olan giriftārum kelimesinin mefā'î̀ün cüz'üyle teḳābülü mümkündür.

Bir de taḳtịide melfūẓa i'tibār olunur; mektūba i'tibār olunmaz. Melfūẓ olan ḥarf mektūb olmasa bile taḳți' de ḥesāba dāhil olur.

\section{Evzān-1 Meşhūre}

Remel'den:

1.

Fā'ilātün fã'ilātün fā'ilātün fā'ilāt

[Āteşīn rūyuñdan olmış bak süveydā ġark-ı nūr

Ṭūrı gūyā eylemiş berḳ-ı tecellā goark-ı nūr]

Aḥmed Ḥamdī Beğ

Āteşīn rū / yuñdan olmış / baḳ süveydā / garḳ-ı nūr

Ṭūrı gūyā / eylemiş ber / ḳ-1 tecellā / garḳ-ı nūr 
T/'Arabī, Fārisī kelimātda vāḳi' olan /ā/ iki ḥarf maḳāmına ḳā'im olur.

Āteşiñ'deki /yā/ mektūb oldug̉u hālde melfūz olmadig̀ından taḳṭi'de ḥesāba dāhil olmaz. Berḳ mużāfınıñ imāle-i kesresinden ḥāṣıl olan /yā/ ise bi'l-'akis mektūb olmadig̀ı hạālde melfūz oldugiundan taḳtị' de ḥesāba dāhil edilir.

Olmış'iñ hemzesi vaṣl oldugundan mektūb-1 gayr-1 melfūz ḳabīlinden olur. Bundaki vāv gibi bak'daki elif ile Ṭūr'ı'daki yā dahi o ḳabīldendendir.

2.

Fā'ilātün fã'ilātün fā'ilātün fā'ilün

[Āyet-i nūr-ı ruhuñ ol dem ki tertī eylerem

Rūḥ-ı Dāvūdı menākıı-ḩōān tebcīl eylerem]

8. Āyet-i nū / r-1 ruhuñ ol / dem ki tertī / 1 eylerem

Rūḥ̣-1 Dāvū / dı menāḳıb / -ḩvān tebcī / l eylerem

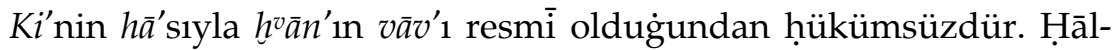

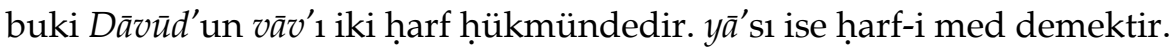

Beynlerindeki fark birinciniñ cüz'-i ahīiri fấ'ilāt, ikinciniñ cüz'-i ahīiri bir sākiniñ isḳāṭyla fā'ilün olmaḳtan 'ibāret bulunan bu iki vezn bir beyitte ictimā' edebilir. Gerek mıșrā'-1 evveliñ, gerek mıșrā'-1 șānīiniñ birinci veya ikinci vezne taṭīịi cā'izdir.

[Gülsitānda ba'd-ezīn olmam harîifi' 'andelīb

Nev-bahārl 'ömrümüñ geçdi hazānım söylüyor]

Şeyh Vașfi Efendi (Şeyh Vasfî 1884: 25)

Gülsitānda / ba'd-ezīn ol / mam ḥarifi-i / 'andelīb

Fā'ilātün / fā'ilātün / fā'ilātün / fā'ilāt

9) Nev-bahārı / ’ömrümüñ geç / di hazānım / söylüyor

Fā'ilātün / fā'ilātün / fā'ilātün / fā'ilün

Gülsitānda'ki hā, dālin imāle-i fetḥası sāyesinde bir harf-i melfūẓ ḥükmünü alır. 
[İsterem bir dem cemāl-i yārdan dūr olmasun

Gizlesün dīdārını āğyārdan her ān nikāa] ]

İsterem bir / dem cemāl-i / yārdan dū / r olmasun

Fā'ilātün / fā'ilātün / fā'ilātün / fā'ilün

Gizlesün dī / dārını āg / yārdan her / ān niḳāb

Fā'ilātün / fā'ilātün / fā'ilātün / fā'ilāt

Yārdan dū / yārdan her cüz'leri esnā-yı taḳtịi de rā'ların kesriyle telaffuz olunur.

3.

Fā'ilātün fā'ilātün fā'ilāt

[Feyż-i hikmetden olinca böyle dūr

Kendimi eyler miyim 'arż-ı hüìūr]

Maḥmūd Kemāleddīn Efendi

110) Feyż-i hịmet / den olınca / böyle dūr

Kendimi ey / ler miyim 'ar / ż-1 ḥużūr

4.

Fā'ilātün fā'ilātün fā'ilün

[Bir ġarīb-i 'ācizi şād eyledüin

Bir yıkılmış kalbi ābād eyledüñ]

Bir garāib-i / 'ācizi şā / d eyledüñ

Bir yıḳılmış / ḳalbi ābā / d eyledüñ

$\mathrm{Bu}$ iki vezn bir beytde ictimā' edebilir. Mıșrā'lardan her biriniñ birinci veya ikinci vezne taṭīịi cā'izdir.

[Eylemem Lokmāna 'arż-ı ihtiyāc

Terk-i cāndur derd-i 'aşkuñ çāresi]

Eylemem loḳ / māna 'arż-1 / iḥtiyāc

Fā'ilātün / fā'ilātün / fā'ilāt

Terk-i cāndur / derd-i 'aşḳuñ / çāresi

[Fā'ilātün / fā'ilātün / fā'ilün]

Mu'allim Feyżì Efendi 
Cān'daki elif ma'zūldür. Sỉ'deki yā bir ḥarf-i melfūz yerini țutar. Bu hāāde müstahlef olmuş olur.

[Bī-niyāz olsam ne var devrāne ben

Sāye-i vaṣluñda oldum kām-kār]

1]1 Bī-niyāz ol / sam ne var dev / rāne ben

Fā'ilātün / fā'ilātün / fā'ilün

Sāye-i vaṣ / luñda oldum / kām-kār

Fā'ilātün / fā'ilātün / fā'ilāt

Ekrem Beğ

Sāye-i' gibi mużāflarıñ imāle-i kesresinden hạaṣıl olan yā dahi bir hạff-i melfūz șayılır.

5.

Fā'ilātün fe'ilātün fe'ilātün fe'ilāt

[Āferīn ey zafer-ārāste-i hākeān-ı dilīr

Hayder-i devr-i (ï) zamān pādişeh-i 'arş-serīr]

Āferīn ey / zạfer-ārās / te-i hāạāa / n-1 dilīir

Hayder-i dev / r-i zamān pā / dişeh-i 'ar / ş serīr

Haḳkī Beğ (Hakkî Bey 1875: 10)

6.

Fā'ilātün fe'ilātün fe'ilātün fa'lāt

[Feyż-i ihsānn eğer eylese ebre te'sīir

Haşre dek kațre-i bārāntn eder mürvārīid]

Feyż-i iḥsā / nı eğer ey / lese ebre / te'sīir

Haşre dek ḳaṭ / re-i bārā / nın eder mür / vārīd

Kāẓım Paşa (Kâzım Paşa 1890: 11)

7.

Fe'ilātün fe'ilātün fe'ilātün fe'ilāt

[Leb-i cāmında nühü̈te dem-i enfās-ı Mesīh

Mey-i nābında 'ayān nūrr-ı hudāvend-i vahīid] 
112 Leb-i cāmın / da nühüfte / dem-i enfās / -1 Mesīh

Mey-i nābın / da 'ayān nū / r-1 hudāven / d-i vahịid “"'[Kāẓım Paşa] (Kâzım Paşa 1890: 9)

8.

Fe'ilātün fe'ilātün fe'ilātün fa'lāt

[Harem-i hāṣṣina dāhil olamazlar eclāf

'Ulemānuñ eder āmālini dā'im is'âf]

Harem-i hāạ / șına dāhil / olamazlar / eclāf

'Ulemānuñ / eder āmā / lini dā'im / is'āf

9.

Fā'ilātün fe'ilātün fe'ilātün fe'ilün

[Her ne dem rūḥ gibi nezdime cānāne gelir

Cān temāşāası içün tā ser-i müjgāne gelir]

Her ne dem rū / ḥ gibi nez / dime cānā / ne gelir

Cān temāşā / sı içün tā / ser-i müjgā / ne gelir

Ekrem Beğ

10.

Fā'ilātün fe'ilātün fe'ilātün fa'lün

['Ālemüñ 'unșur u eczāsı perīşān olsa

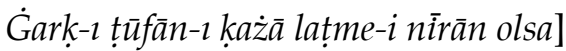

1 133 ' Âlemüñ 'un / șur u eczā / sı periş̧ā / n olsa

Ġarḳ-1 ṭūfā / n-1 ḳażā laṭ / me-i nīrā / n olsa

Hurūf-1 imlādan olan hā āhir-i mıṣrā'da vāḳı' olunca bir ḥarf-i melfūz yerini țutar. Hā'-i resmiyye de böyledir. 
11.

Fe'ilātün fe'ilātün fe'ilātün fe'ilün

[Bakıyor mu diye dil-haste-i hicrān gözüme

Baḳıyor cān alıcı gözleri yan yan gözüme]

Baḳıyor mu / diye dil-ḩas / te-i hicrān / gözüme

Baḳıyor cā / n alıcı göz / leri yan yan / gözüme

'Alìi Rūhīi Beğ (Leme'āt) (Ali Rûhî 1884: 59)

12.

Fe'ilātün fe'ilātün fe'ilātün fa'lün

[Ne șabā șā'ika dersem yaraşır sür'atde

Ki seğirdirken aña sāyesi olmaz hem-pā]

Ne ṣabā șā / 'iḳa dersem / yaraşır sür / 'atde

Ki seğirdir / ken aña sā / yesi olmaz / hem-pā

Aña'daki elif müstaḩlef oldugiundan bir harf-i melfūz yerini țutar. Bu sekiz ${ }^{1} \Lambda_{ \pm}$șūretden her biri dahi digeriyle bir beytde ictimā' edebilir.

Mis̄āl īrādına lüzūm görmüyoruz.

13.

Fā'ilātün fe'ilātün fe'ilāt

[Ey bihìn nüsha-i mecmū'a-i zāat

Nakşs-ı zïbende-i mir'ät-ı șı fät]

Ey bihīn nüs / ḩa-i mecmū / 'a-i zāāt

Naḳş-1 zìben / de-i mir'ā / t-1 șıfāt

Nābī (Kaplan 1995: 327. b)

14.

Fā'ilātün fe'ilātün fa'lāt

[Enbiyā șadr-1 serīr-i i ${ }^{\prime} z \bar{a} z$

Her biri bedr-i münīr-i $\left.i{ }^{\prime} c \bar{a} z\right]$ 
Enbiyā ṣad / r-1 serīir-i / i'zāz

Her biri bed / r-i münīr-i / i'cāz

“"'[Nābī] (Kaplan 1995: 38. b)

15.

Fā'ilātün fe'ilātün fe'ilün

[Öyle mülhidde kerāmet mi olur

Evliyā ehl-i dalālet mi olur]

Öyle mülhịid / de kerāmet / mi olur

115 Evliyā eh / 1-i ḍalālet / mi olur

Sünbülzāde Vehbī (Beyzadeoğlu 2004: 230. b.)

16.

Fā'ilātün fe'ilātün fa'lün

[Ișțtīạ üzre tekellüm eyler

Bakup ețrāfa tebessüm eyler]

Ișṭlāḥ üz / re tekellüm / eyler

Baḳup ețrā / fa tebessüm / eyler

“”'[Sünbül-zāde Vehbī] (Beyzadeoğlu 2004: 399. b.)

17.

Fe'ilātün fe'ilātün fe'ilāt

[Meğer olmışdı o sìmā yı besīm

Șadef-i ma' rifete dürr-i yetīm]

Meğer olmış / dı o sīmā / yı besīm

Șadef-i ma' / rifete dür / r-i yetīm

Ḩāḳānī (Külekçi 1988: 354. b.)

Ḥarf-i müşedded iki ḥarf hüükmündedir. 
18.

Fe'ilātün féilātün fa'lāt

[Ṭag̀ıdur halka müzeyyef tārih

Olarak lāyık-ı leom ü tevbih]

Ṭağıdur hal / ḳa müzeyyef / tārīh

Olaraḳ lā / yıḳ-ı levm ü / tevbīh

Sünbül-zāde Vehbī (Beyzadeoğlu 2004: 669. b.)

11 (6. Vā̃ dāhil edilir. Żammesi imāle edilen vāv-ı mafșūle de böyledir.

19.

Fe'ilātün fe'ilātün fe'ilün

[Saña 'izzet vericek yerde fenā

Sen edersin an $\bar{a}$ lāt-ı hevā]

Saña 'izzet / vericek yer / de fenā

Sen edersin / anı ālā/ t-ı hevā

Nābī (Kaplan 1995: 1305. b)

20.

Fe'ilātün fe'ilātün fa'lün

[Koparur hașmı ile da'vāyı

Unudur āhiret ü dünyāyl]

Koparur haș / mı ile da' / vāyı

Unudur ā / hiret ü dün / yāyı

“"'[Nābī] (Kaplan 1995: 1337. b)

21.

Fe'ilātü fā'ilātün fe'ilātü fā'ilātün

[Yine zevrak-ı derūnum kırnlıp kenāre düştü

Țayanır mı şişsedür bu reh-i seng-sāre düştü] 
Yine zevra / ḳ-1 derūnum / ḳırılıp ke / nāre düştü

Ṭayanır mı / şiş̧edür bu / reh-i seng / sāre düştü

Şeyh Ğālib (Okçu 1993: G.311/1)

\section{$1[7 /$ Hezec}

1.

Mefā'î̀ïn mefā'î̀iun mefā'î̀ün mefā'î̀ün

Bu derd-i ser nedir her derde dārū bādedir sözde

Esìr-i bāde olmuş rindimiz āzādedir sözde

[Bu derd-i ser / nedir her der / de dārū bā / dedir sözde

Esīr-i bā/ de olmuş rin / dimiz āzā / dedir sözde]

Bunuñ ikinci ve dördüncü cüz'lerinde, yāhud yalñı ikinci veya dördüncü cüz'ünde bir harf-i sākin ziyāde edilebilir. O hạālde mefā'î̀ün, fe ūlün fā' olur. Faḳat bu șūretlerden birincisi az ḳullanılır.

Meselā

Uzakdan seyr edip de ehl-i sa'yi etme istiṣğār

mișrā's Mefā'îlün mefā'î̀ün mefā'î̀ïn fe' ūlün fă' veznindedir.

Bu dört vezniñ ictimā' 1 cā'izdir.

11832.

Mefā'î̀ü mefā'īiün

Senü̃n'çün ey gül-i ra'nā

Neler çekdim neler çekdim

[Senüñ'çün ey / gül-i ra'nā

Neler çekdim / neler çekdim]

Bunuñ dahi ikinci cüz'üñde bir sākin ziyāde edilebilir. O hạalde yine Mefā'î̀ïn, Fe' ūlün fā' olur.

Meselā

Tehī mi etdiğim feryād mıșrā'1 Mefā'îlün fe' ūlün fā' veznindedir. Bunlarda da ictimā' cā'izdir. 
3.

Mefā'îiün mefā'î̀ün mefā'îl

Niyāz etdikçe ben sen eylediñ nāz

[Niyāz etdik / çe ben sen ey / lediñ nāz]

19.

Mefā'î̀ün mefā'î̀ün fe' ūlün

Baña sensiz cihānda cān ne lāzım

[Baña sensiz / cihānda cān / ne lāzım]

5.

Mef'ūlü mefā'î̀ïn mef'ūlü mefā'îlün

Koyma kadehi elden söz pìr-i mug்āniñdır

[Ḳoyma ḳa / deḥi elden / söz pīr-i / mugiānıñorı]

Bunuñ dahi ikinci ve dördüncü cüz'lerinde, yāhud yalñı ikinci veya dördüncü cüz'ünde bir sākin ziyāde edilebilir. $O$ hāalde yine Mefā'î̀ün, Fe' ūlün fā' olur. Meselā:

'Ayyūḳa çıkar feryād, gūyā ki ḳıāmetdir

['Ayyūḳa / çıḳar feryād / gūyā ki / ḳıyāmetdir]

mișrā' 1 Mef'ūlü fe' ūlün fā', mef' ūlü mefā'î̀ün veznindedir.

20 §

6.

Mef'

Ey kudretiñe olmayan āògaz u tenāhī

[Ey ḳudre / tiñe olma / yan āgāz u / tenāhī] 
7.

Mef'ūlü mefā'ilün mefā'īl (İctimā'1 cā'iz)

Ey akşamı [sim]siyāh eden māh

[Ey aḳşa / mı [sim]siyāh / eden māh]

8.

Mef'ūlü mefā'ilün fe' ūlün

Nāmeñ dil-i zāre vāṣıl oldu

[Nāmeñ di / l-i zāre vā / șıl oldu]

9.

Mef'ūiün fā'ilün mefā'īl

Der her şey'iñ lisānı her-gāh

[Der her şey / 'iñ lisān / 1 her-gāh]

2110 .

Mef'ūlün fā'ilün fe'ūlün

Cāhil kaldı żarìr olanlar

[Cāhil ḳal / dı żarīr / olanlar]

Bu vezni, Mef'ūlü mefā'ilün mefā'î̀l veya Mef'ūlü mefā'ilün fe'ūlün vezniyle cem' etmemelidir.

Yalñız

Deryā deryā dökerdi yaşı

gibi mükerrerātda tecvīz olunur.

11.

Mef'ūlü mefā'î̀ün

Düşdüm yine bir derde

[Düşdüm yi / ne bir derde] 
Bunuñ dahi ikinci cüz'ünde bir sākin ziyāde edilebilir. O hāālde yine Mefā'īlün, $F e^{\prime}$ ūlün fā' olur. Meselā,

2 22Y Yokdur baña bir $\dot{g} a m-h^{v} \bar{a} r$ mıṣrā's Mef'ūlün fe' ūlün fă' veznindedir. [İctimā's cā'iz].

$\S$

\section{Recez}

1.

Müstef'ilün müstef'ilün müstef'ilün müstef'ilün

Ol āfitā / b-1 salțanat / ol şeh-süvā / r-1 memleket

[Ol âfitāb-ı salțanat ol şeh-süvār-ı memleket]

2.

Müstef'ilün müstef' ilāt müstef'ilün müstef'ilün

Leşker-şikā / r-1 kām-kār / Behrām-1 Ef / rīdūn-'alem

[Leşker-şikār-ı kām-kār Behrām-ı Efrìdūn-'alem]

3.

Müstef'ilün müstef'ilün müstef'ilün müstef'ilāt

Behrām-1 Ef / rīdūn-'alem / leşker-şikā / r-1 kām-kār

[Behrām-ı Efrìdūn-'alem leşker-şikār-ı kām-kār]

4.

Müstef'ilün müstef'ilāt müstef'ilün müstef'ilāt

Eblaḳ-süvā / r-1 rūzgār / āşūb-1 Rū / m-1 Zengibār

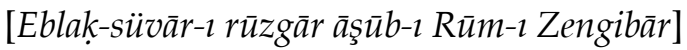

$2{ }^{2} \hat{3} \mathrm{Bu}$ dört șūretiñ ictimā' 1 cā'izdir. Birer mișrā'dan 'ibāret görülen bu șūretler ikiye bölünerek birer beyt şekline ḳonulabilir. O yolda tertīb edilen beyte Murabba'-ı meşțūr nāmı verilir. 


\section{5.}

Müfte'ilün müfte'ilün müfte'ilün müfte'ilün

Taālib-i fen / n-i edebiz / sālib-i hav / f-1 ta'abız

[Ṭālib-i fenn-i edebiz sālib-i havf-ı ta'abız]

6.

Mefā'ilün mefā'ilün mefāìlün mefā'ilün

Beyānın ey / ledi 'ayān / serā'ir-i / nihānını

[Beyānın eyledi 'ayān serā'ir-i nihānını]

7.

Müfte'ilün mefā'ilün müfte'ilün mefā'ilün

Müşkil imiş / ki dil-rübā / ț̣fl ola dil / sitān ola

[Müşkil imiş ki dil-rübā tıfl ola dil-sitān ola]

$\mathrm{Bu}$ üç șūretde dahi mıṣrā'lar ikiye bölünerek birer beyt şekline ḳonulabilir. 24 Bu üç șūretiñ ictimā' 1 āhengi bozacağı cihetle cā'iz değildir.

Bir baḥriñ:

Mefā'ilün müfte'ilün mefā'ilün müfte'ilün

$\S$

Müfte'ilün müfte'ilün mefā'ilün müfte'ilün

$\S$

Müfte'ilün müfte'ilün mefā'ilün mefā'ilün

$\S$

Mefā'ilün mefā'ilün müfte'ilün müfte'ilün

gibi șūretleri bir 'Oșmanlı şā'iriniñ tabī'atına pek de muvāfık gelmez. Binā'en-'aleyh bizce onlar isti' māl edilmemek lāzım gelir. 


\section{Kaynaklar}

‘Alî Rūhî (1302/1884), Leme`āt, İstanbul: Mihran Matbaası, 63 s.

Beyzadeoğlu, Süreyya A. (2004), Sünbülzâde Vehbî Lütfiyye (Metin tespiti, özet, yorum ve açıklamalar), İstanbul: Millî Eğitim Bakanlığı Yayınları: 3800, Bilim ve Kültür Eserleri Dizisi: 1346, Araştırma-İnceleme, $173+1 \mathrm{~s}$.

Eraslan, Kemal (1993), Alî-Şîr Nevâyî Mîzânu'l-Evzân (Vezinlerin Terazisi), Ankara: Atatürk Kültür, Dil ve Tarih Yüksek Kurumu Türk Dil Kurumu Yayınları: 568, Alî-Şîr Nevâyî Külliyatı: 14., : XIV+198 s.

Hakkı Bey (1292/1875), Dîvān-ı Hakkî Beğg, Bursa: Hüdavendigâr Vilâyet Matbaasi, $55 \mathrm{~s}$.

Kaplan, Mahmut (1995), Yusuf Nabi Hayriyye-i Nâbî İnceleme-Metin, Ankara: Atatürk Kültür, Dil ve Tarih Yüksek Kurumu, Atatürk Kültür Merkezi Yayını: 94, Mesneviler Dizisi: 1, 6+313 s.

Kâzım Paşa (1308/1890), Dî̀̄̄n-ı Kāzım Paşa, İstanbul: Nümûne-i Tıbaat Matbaasi, $93 \mathrm{~s}$.

Külekçi, Numan (1988), Hakânî Mehmed Bey Hilye, Erzurum: Atatürk Üniversitesi Kâzım Karabekir Eğitim Fakültesi Yayını No: 2, XVII+89 s.

Mu'allim Nâcî (1313/1895), Arûz Nümûnesi, İstanbul: Kasbar Matbaası, $24 \mathrm{~s}$.

Okçu, Naci (1993), Şeyh Galib Hayatı, Edebî Kişiliği, Eserleri, Şiirlerinin Umûmî Tahlili ve Divânın Tenkidli Metni, Ankara: Kültür Bakanlı̆̆ Yayınları/1453, Yayımlar Dairesi Başkanlığı, Türk Klasikleri Dizisi/21, I. C., XI+482 s., II. C., XI+485-1029 s.

Şeyh Vasfî Efendi (1302/1884), Cezebāt, İstanbul: Mihran Matbaası, 48 s. 